\title{
Rak płuca staje się nowotworem dominującym wśród kobiet w Europie
}

\author{
Urszula Sulkowska ${ }^{1}$, Marta Mańczuk ${ }^{1}$, Jakub Łobaszewski ${ }^{1}$, Witold A. Zatoński ${ }^{1}$
}

Wstęp. Artykuł ten ma celu przedstawienie obrazu umieralności wśród kobiet w krajach Unii Europejskiej z powodu nowotworów złośliwych płuca na tle umieralności z powodu raka piersi. Badanie ma także na celu zwrócenie uwagi na czynnik ryzyka nowotworów płuca, jakim jest palenie tytoniu — wciąż rozwijający się problem zdrowia publicznego. Materiał i metody. Materiał będący podstawą tego opracowania stanowią dane o zgonach z powodu nowotworów złośliwych płuca i piersi u kobiet w Polsce i w innych krajach Unii Europejskiej za wszystkie dostępne lata w okresie 1960-2010. Analizę trendów czasowych umieralności z powodu nowotworów złośliwych płuca i piersi przeprowadzono przy użyciu programu Joinpoint Regression Program. Analizą objęto kobiety w wieku 45-74 lat.

Wyniki. Umieralność z powodu raka płuca wśród kobiet rośnie od wielu lat i w większości krajów ta przyczyna zgonów już jest lub w najbliższej dekadzie będzie najczęstszą przyczyną zgonów nowotworowych Europejek.

Podsumowanie. Nowotwory złośliwe płuca stają się pierwszą przyczyną zgonów nowotworowych wśród kobiet w Europie. W większości krajów trendy czasowe umieralności wykazują tendencję wzrostową. Głównym tego powodem jest rozwój epidemii palenia tytoniu wśród kobiet. Leczenie zespołu uzależnienia od tytoniu wydaje się być najskuteczniejszym sposobem na zmianę tych niekorzystnych tendencji. Edukowanie kobiet i wskazywanie efektywnych sposobów zerwania z paleniem papierosów powinno pozostawać priorytetem w zakresie działań prewencji pierwotnej nowotworów i promocji zdrowia.

\section{Lung cancer, the leading cause of cancer deaths among women in Europe}

Introduction. This article presents the picture of mortality from lung cancer among women in the European Union in relation to breast cancer mortality. It also draws attention to tobacco smoking as a main cause of lung cancer and still a significant public health problem.

Material and methods. Data on mortality due to lung cancer and breast cancer among women in Poland and other European Union countries were derived from the WHO mortality statistics for the period 1960-2010. The analysis of time trends in mortality from lung cancer and breast cancer were performed using Joinpoint Regression Program for women aged 45-74 years.

Results. Lung cancer mortality among women has been increasing for many years, and in most countries this is already or will be in the next decade, the leading cause of cancer deaths European women.

Conclusions. Lung cancer is the leading cause of cancer deaths among women in Europe. In majority of countries the mortality time trends are increasing and the main reason for this is a persistent epidemic of tobacco smoking in women. Treatment of tobacco dependence seems to be the most effective way to change these negative trends. Educating women and indicating them to effective ways of smoking cessation should remain a priority of cancer primary prevention and health promotion activities.

NOWOTWORY Journal of Oncology 2015; 65, 5: 395-403

Słowa kluczowe: nowotwory złośliwe płuca, nowotwory złośliwe piersi, Polska, Unia Europejska, palenie tytoniu Key words: lung cancer, breast cancer, Poland, European Union, tobacco smoking 


\section{Wstęp}

Palenie tytoniu jest nadal najpoważniejszym problemem zdrowia publicznego w Europie. W pierwszej połowie XX wieku, kiedy epidemia raka płuca wśród mężczyzn była na ogół w fazie wstępującej, choroba ta była bardzo rzadko obserwowana wśród kobiet. Odzwierciedlało to fakt szeroko rozpowszechnionego zwyczaju palenia tytoniu wśród mężczyzn, przy niskim odsetku palących kobiet.

Kolejne dekady przyniosły powolny, ale postępujący rozwój epidemii palenia tytoniu wśród kobiet, co szybko stało się wyraźnie widoczne w przebiegach trendów umieralności z powodu raka płuca. Współczynniki umieralności $z$ tej przyczyny pod koniec drugiej połowy XX wieku dla mężczyzn z krajów europejskich osiągnęły szczyt i zaczęły spadać, natomiast trendy umieralności z powodu raka płuca dla kobiet w wielu krajach europejskich nadal wykazują tendencję wzrostową. Konsekwencją tego jest fakt, że rak piersi, będący od lat najczęstszą przyczyną zgonów nowotworowych w populacji kobiet w Europie przestaje być już nowotworem dominującym, a nowotwory złośliwe płuca stają się pierwszą przyczyną zgonów nowotworowych wśród kobiet.

Artykuł ten ma celu przedstawienie obrazu umieralności wśród kobiet w krajach Unii Europejskiej z powodu nowotworów złośliwych płuca na tle umieralności z powodu raka piersi. Badanie ma także na celu zwrócenie uwagi na czynnik ryzyka, jakim jest palenie tytoniu - wciąż narastający problem zdrowia publicznego.

\section{Materiał i metody}

Materiał będący podstawą tego opracowania stanowią dane o zgonach z powodu nowotworów złośliwych płuca i piersi u kobiet w Polsce i w innych krajach Unii Europejskiej, za wszystkie dostępne lata w okresie 1960-2010. Cypr został wyłączony z analizy z powodu zbyt krótkiego czasu obserwacji (od 2004 r.).

Dane o umieralności pochodzą z bazy Światowej Organizacji Zdrowia (WHO) i są oficjalnymi statystykami. Baza ta zawiera informacje o liczbie zgonów według przyczyn określonych w Międzynarodowej Klasyfikacji Chorób (ICD), w podziale na płeć i 5-letnie grupy wieku. Dane na temat wielkości populacji zostały zaczerpnięte z tego samego źródła. Zarówno dane, jak i ich szczegółowy opis zawarty w dokumentacji dostępne są na stronie internetowej WHO [1].

W pracy analizowano zgony kobiet, których przyczyną był nowotwór złośliwy płuca określony w VII rewizji ICD numerami 162-163, w VIII i IX numerem 162, a w X kodami C33 i C34, lub rak piersi klasyfikowany jako $\mathrm{nr} 170 \mathrm{w}$ VII rewizji ICD, nr 174 w VIII i IX oraz kodem C50 w rewizji X. Z powodu strajku lekarzy w Polsce w latach 1997-1998 nie są dostępne dane o umieralności wg przyczyn. Dane za lata 1997 i 1998 przedstawione na wykresach obrazują średnią umieralność z lat 1996 i 1999. Wartości współczynników umieralności dla Luk- semburga i Malty są wynikiem 3-letniej średniej ruchomej dla danego roku, roku poprzedniego i kolejnego. Umieralność dla Niemiec z okresu 1972-1989 jest umieralnością obserwowaną łącznie na terenie byłego RFN i NRD.

Przeprowadzona analiza opiera się na podstawowym wskaźniku epidemiologicznym, jakim jest standaryzowany według wieku i metodą bezpośrednią współczynnik umieralności z powodu ww. nowotworów. Jako populację standardową przyjęto „standardową populację świata”. Analizą objęto kobiety w wieku 45-74 lat z względu na występowanie największej liczby zgonów z powodu nowotworów złośliwych płuca i piersi w tym przedziale wieku.

Analizę trendów czasowych umieralności z powodu nowotworów złośliwych płuca i piersi przeprowadzono przy użyciu programu Joinpoint Regression Program w wersji 3.4.3. Oprogramowanie to umożliwia testowanie, czy zmiany trendu czasowego współczynników w analizowanym okresie są istotne statystycznie. Analiza rozpoczyna się od dopasowania linii trendu do danych i sprawdzania, czy jeden lub więcej punktów przełomu (do 3) prowadzi do uzyskania lepszego modelu.

Dla krajów, w których trendy umieralności z powodu nowotworów złośliwych płuca i raka piersi nie przecięły się do 2010 r., linie trendów zostały przedłużone do 2020 r. w oparciu o przebieg ostatnio obserwowanego trendu (od ostatniego punktu przełomu), z wyjątkiem krajów, dla których przebiegi trendów były rozbieżne.

\section{Wyniki}

Nowotwory złośliwe płuca w części krajów europejskich są już teraz pierwszą przyczyną zgonów nowotworowych wśród kobiet; w innych poziom umieralności z powodu raka piersi i nowotworów złośliwych płuca jest zbliżony, a co za tym idzie, przecięcie obserwowanych linii trendów umieralności z powodu tych przyczyn najprawdopodobniej nastąpi wkrótce. Są także kraje w których nadal poziom umieralności z powodu raka piersi jest znacznie wyższy niż z powodu nowotworów złośliwych płuca, a także kraje takie, dla których przebiegi trendów umieralności z tych przyczyn nie są zbieżne. Charakterystykę przebiegu trendów umieralności w poszczególnych krajach przedstawia tabela I.

Dania jest krajem, w którym linie przebiegu trendów umieralności z powodu nowotworów złośliwych płuca i raka piersi przecięły się najwcześniej (ryc. 1). Już od 1991 r. nowotwór złośliwy płuca był tam dominującą przyczyną zgonów wśród kobiet. Począwszy od 1996 r. umieralność z tej przyczyny zaczęła maleć, ale tempo spadku umieralności $z$ powodu raka piersi było $w$ tym okresie znacznie szybsze. Pierwsza dekada XXI wieku obrazuje już zdecydowanie wyższą umieralność z powodu nowotworów złośliwych płuca wśród Dunek w wieku 45-74 lat (95/100 000 populacji) niż z powodu raka piersi (60/100 000 populacji). Kolejnym krajem, w którym od 1999 r. obserwuje się wyższą umieralność 


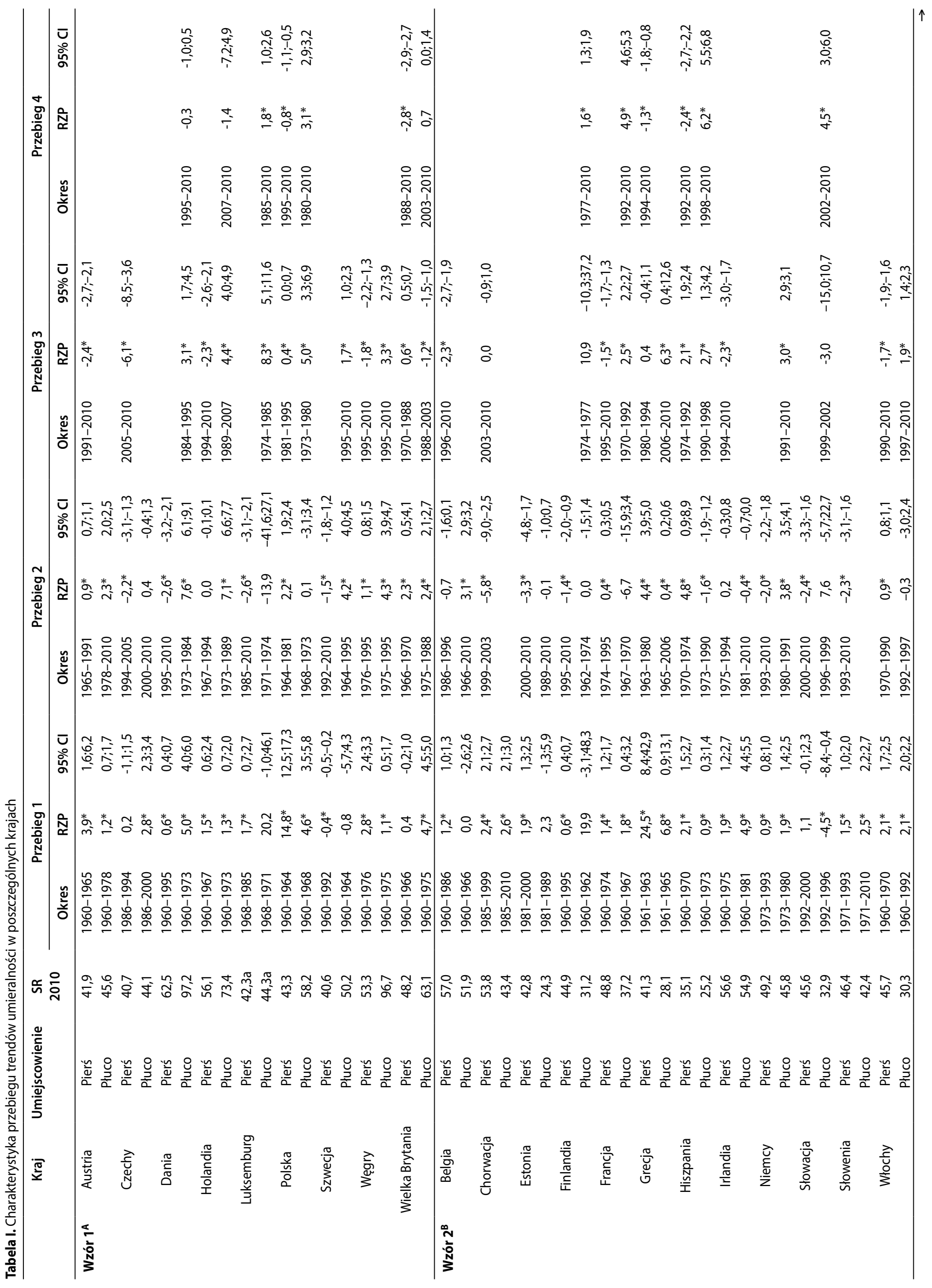




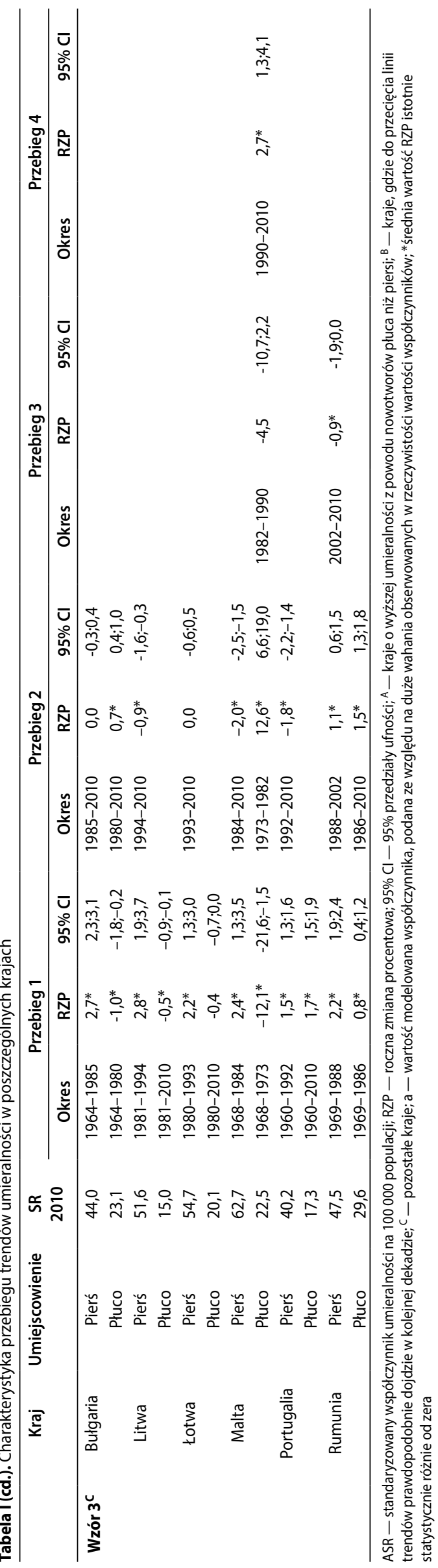

z powodu nowotworów złośliwych płuca niż piersi, są Węgry. W 2010 r. wartość współczynnika umieralności z powodu nowotworów złośliwych płuca wynosiła 95/100 000 populacji, należy przy tym jednak zaznaczyć, że w odróżnieniu od sytuacji kobiet w Danii trend umieralności dla tej przyczyny zgonów od 1975 r. nadal istotnie statystycznie rośnie.

Na początku XXI wieku także w Holandii, Polsce, Szwecji i wWielkiej Brytanii doszło do przecięcia linii trendów umieralności z powodu analizowanych przyczyn, co oznacza wyższą umieralność z powodu raka płuca niż z powodu raka piersi. W każdym z tych krajów spada umieralność z powodu raka piersi, ale przebiegi trendów umieralności dla nowotworów złośliwych płuca są różne. Umieralność z tej przyczyny wciąż rośnie w Polsce i Szwecji, w Holandii po 2007 r. obserwuje się spadek, natomiast w Wielkiej Brytanii spadkowy trend obserwowany po 1989 r. odwrócił się, i od 2003 r. umieralność z powodu nowotworów złośliwych płuca wśród kobiet w wieku 45-74 lat ponownie zaczęła wzrastać.

Pod koniec przyjętego okresu obserwacji do przecięcia trendów umieralności z powodu raka piersi i nowotworów złośliwych płuca doszło także w Austrii, Czechach i Luksemburgu. W krajach tych obserwuje się spadek umieralności z powody raka piersi i wzrost umieralności z powodu nowotworów złośliwych płuca.

Kolejną grupę krajów tworzą Belgia, Francja, Grecja, Hiszpania, Niemcy, Słowacja i Słowenia. W krajach tych, przy założeniu kontynuacji ostatnio obserwowanych trendów, nowotwór złośliwy płuca najprawdopodobniej stanie się dominującą przyczyną zgonów wśród kobiet w wieku 45-74 lat między 2010 a 2020 rokiem. W grupie tych państw obserwuje się stały spadek umieralności z powodu raka piersi i wzrost z powodu nowotworów złośliwych płuca (ryc. 2). Krajem, w którym także prawdopodobnie w kolejnych latach dojdzie do przecięcia linii trendów, jest także Irlandia. Specyfiką tego państwa, w odróżnieniu do innych krajów $z$ tej grupy, jest jednak to, że od początku lat 80 . notuje się tam stały spadek umieralności z powodu nowotworów złośliwych płuca. Tempo tego spadku jest jednak znacznie niższe niż tempo spadku umieralności z powodu raka piersi.

W przypadku Chorwacji, Estonii, Finlandii i Włoch do przecięcia linii trendów może dojść ok. 2020 r. lub nieco później, przy czym w Finlandii i we Włoszech obserwuje się przebiegi trendów takie jak w większości krajów z tej grupy — spadek umieralności z powodu raka piersi i wzrost z powodu nowotworów złośliwych płuca. W Chorwacji umieralność z powodu nowotworów złośliwych płuca rośnie wykładniczo, natomiast umieralność z powodu raka piersi od 2003 r. pozostaje na mniej więcej takim samym poziomie (ok. 52/100 000 populacji). Umieralność z powodu raka piersi wśród kobiet w Estonii od 2000 r. maleje w bardzo szybkim tempie, umieralność na nowotwory złośliwe płuca od $1990 \mathrm{r}$. utrzymuje się na stałym, relatywnie niskim poziomie (ok. 25/100 000 populacji). 


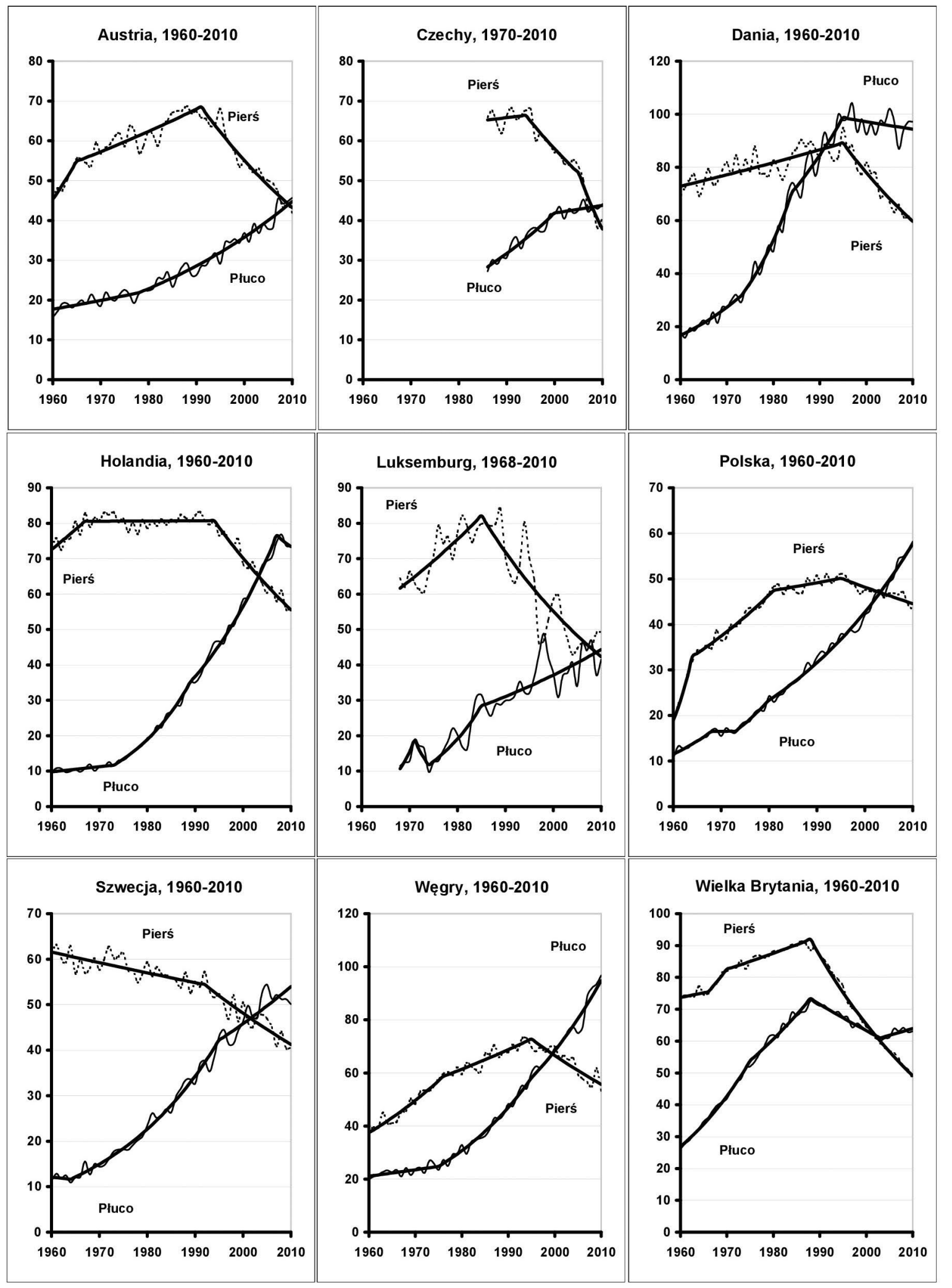

Rycina 1. Umieralność z powodu nowotworów złośliwych piersi i płuca wśród kobiet w wieku 45-74 lat — kraje o wyższej umieralności z powodu nowotworów płuca niż piersi 


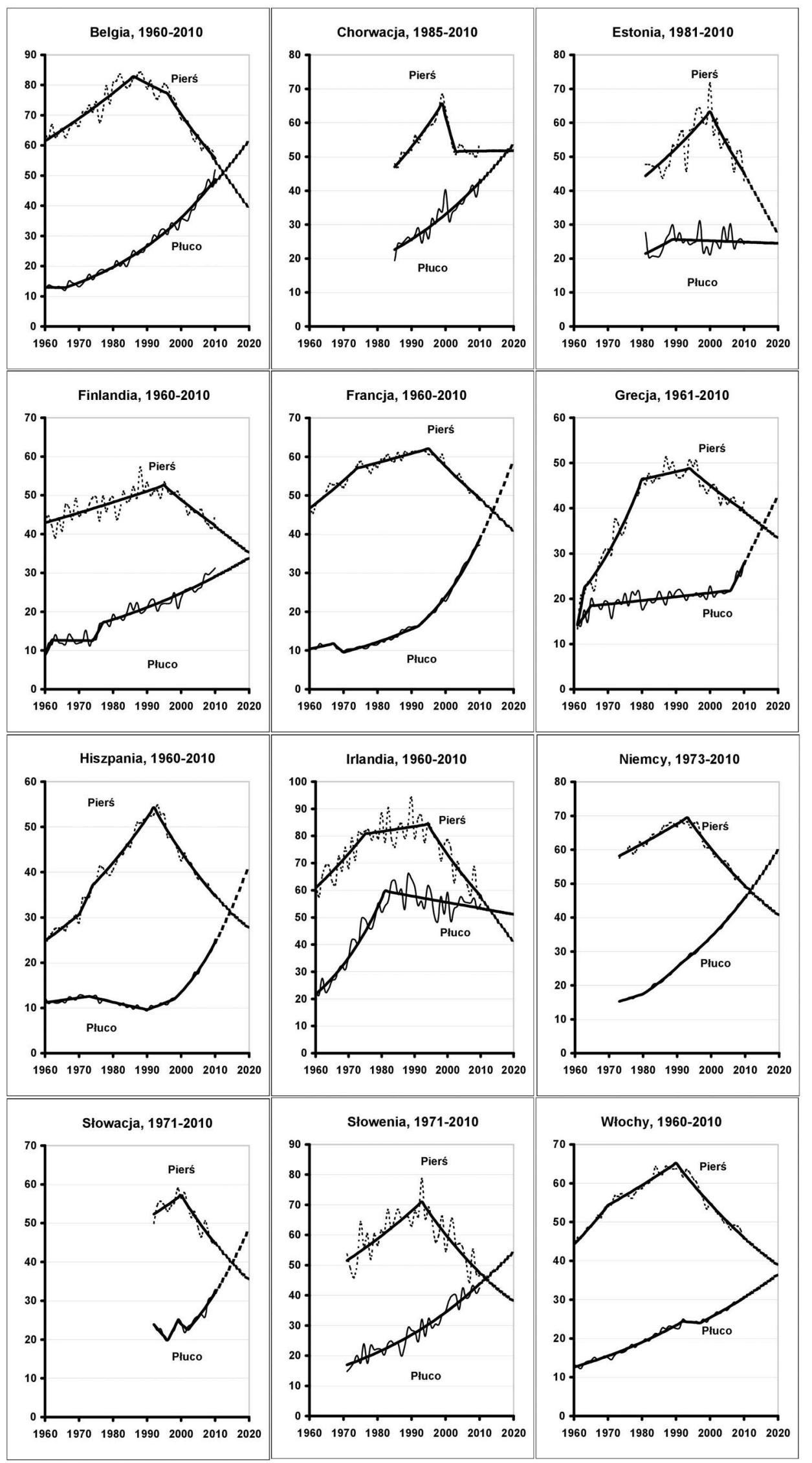

Rycina 2. Umieralność z powodu nowotworów złośliwych piersi i płuca wśród kobiet w wieku 45-74 lat — kraje, gdzie do przecięcia linii trendów dojdzie w kolejnej dekadzie 


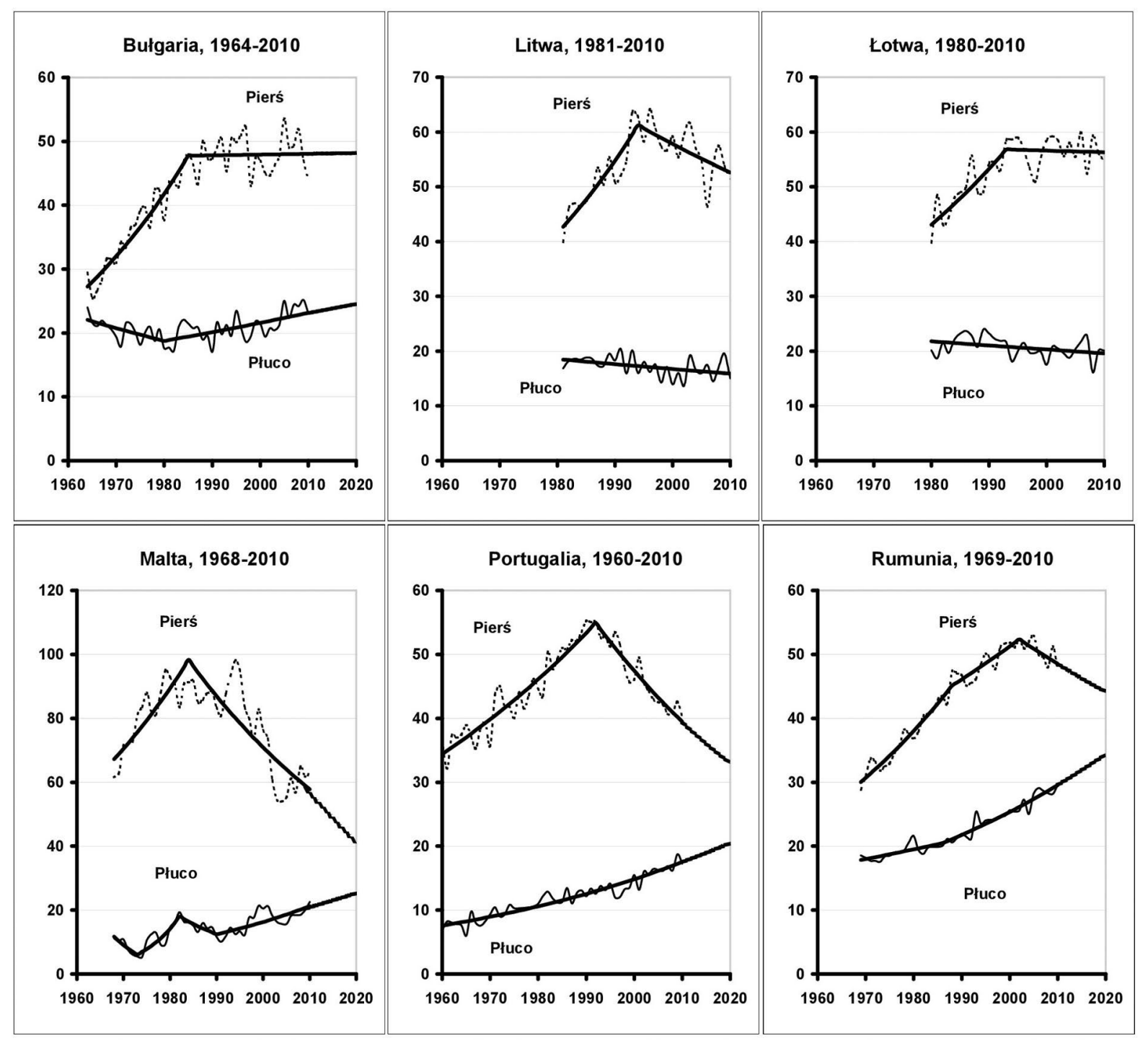

Rycina 3. Umieralność z powodu nowotworów złośliwych piersi i płuca wśród kobiet w wieku 45-74 lat — pozostałe kraje

Ostatnią analizowaną grupę krajów stanowią: Bułgaria, Litwa, Łotwa, Malta, Portugalia i Rumunia. Na Litwie i Łotwie umieralność zarówno z powodu nowotworów złośliwych płuca, jak i raka piersi maleje — przebiegi tych trendów nie są zbieżne. W Bułgarii obserwuje się stały poziom umieralności z powodu raka piersi, znacznie wyższy niż z powodu nowotworów złośliwych płuca, wykazujących od początku lat 80. tendencję wzrostową. Linie przebiegu trendów umieralności z powodu nowotworów złośliwych płuca dla Malty, Portugalii i Rumunii wykazują stały wzrost. W krajach tych jednak także obserwuje się spadek umieralności z powodu raka piersi (ryc. 3).

\section{Dyskusja}

Jeszcze w poprzedniej dekadzie dominującą lokalizacją nowotworową, powodującą najwyższą umieralność wśród kobiet w Europie i prawie na całym świecie był rak piersi [2].
Ten obraz epidemiologiczny nie jest już aktualny. Umieralność z powodu raka piersi w większości krajów w Europie zaczęła spadać, lub co najmniej przestała rosnąć. Ma to związek w dużej mierze z postępem w leczeniu raka piersi oraz wprowadzeniem badań przesiewowych w kierunku wykrywania raka piersi, aczkolwiek wpływ wczesnej diagnostyki i badań przesiewowych na spadek umieralność z powodu raka piersi jest nadal przedmiotem dyskusji [3].

Umieralność z powodu raka płuca wśród kobiet, choroby związanej prawie wyłącznie z paleniem tytoniu, rośnie od wielu lat, i w większości krajów europejskich rak płuca stał się już lub w najbliższej dekadzie będzie najczęstszą przyczyną zgonów nowotworowych wśród kobiet.

Wzrost umieralności na nowotwory płuca w poszczególnych krajach europejskich najprawdopodobniej wynika z wzorców częstości palenia tytoniu. Dania jest krajem, w którym już na początku lat 50. XX wieku odsetek palących 
kobiet wynosił ok. 40\%, między 1970 a 1980 rokiem aż 45\% [4], a w latach 90. był najwyższy wśród krajów UE — 37\% palących kobiet (i tyle samo mężczyzn) [5]. Właśnie w tym kraju linie przebiegu trendów umieralności z powodu nowotworów złośliwych płuca i raka piersi przecięły się najwcześniej, co oznacza dominację nowotworów złośliwych płuca nad nowotworami piersi.W Polsce częstość palenia wśród kobiet w wieku 20 i więcej lat jeszcze w roku 1974 wynosiła ok. 19\%, podczas gdy niecałą dekadę później (w 1982 roku) wzrosła do $32 \%$ [6]. W kolejnych latach odsetek ten wahał się od $26 \%$ do $22 \%[6,7]$. Na Węgrzech, gdzie analizowane trendy umieralności przecięły się jeszcze wcześniej niż w Polsce, odsetek palących kobiet od lat utrzymuje się na wysokim poziomie - w 1988 roku wynosił $29 \%$ wśród kobiet w wieku powyżej 15 lat [8] i praktycznie nie zmienił się on w kolejnych latach: w 2003 roku paliła prawie jedna trzecia (31\%) kobiet w wieku 15-64 lat [9], w 2010 odsetek ten wyniósł 29\% w populacji kobiet $\mathrm{w}$ wieku $15 \mathrm{i}$ więcej lat [7].

Kraje, w których umieralność z powodu raka płuca utrzymuje się na stałym poziomie, takie jak Litwa i Łotwa, charakteryzuje nieco inny obraz zjawiska palenia tytoniu wśród kobiet - palenie nigdy nie było w tych krajach tak szeroko rozpowszechnione jak w Polsce lub w niektórych krajach Europy Zachodniej. Na Łotwie na przełomie XX i XXI wieku odsetek palących kobiet utrzymywał się na poziomie ok. 20\% [10], by spaść do poziomu 16\% w roku 2010 [7]. Na Litwie odsetek palących kobiet jeszcze w 1994 roku wynosił 6\%, ale niecałą dekadę później (w roku 2002) był już dwukrotnie wyższy (13\%) i przewidywany jest jego dalszy wzrost [10]. Kolejne lata obserwacji pokażą, jak zmieni się sytuacja epidemiologiczna w zakresie umieralności na tytoniozależne nowotwory w tych krajach.

Zmiany częstości palenia tytoniu przez kobiety miały najprawdopodobniej związek ze spadkiem umieralności spowodowanej rakiem płuca także w takich krajach jak Wielka Brytania czy Irlandia. Odsetek palących kobiet w tych państwach osiągnął szczytową wartość w latach 70. ubiegłego wieku, przekraczając poziom nawet $40 \%$, by potem stopniowo spadać [11]. W Anglii jeszcze w latach 1960 do palenia tytoniu przyznawało się 40\% kobiet; w 2013 roku odsetek ten był niższy o połowę (19\%) [12]. Także w pozostałych krajach Wielkiej Brytanii w ostatniej dekadzie wiele badań potwierdziło spadek częstości palenia wśród kobiet [13]. W Irlandii ogólna częstość palenia w populacji spadła o 14\% między 1985 a 2000 r. [14], a odsetek palących kobiet zmniejszył się z 32\% w roku 1998 do 27\% w roku 2007 [15].

Jak pokazał przykład mężczyzn w poprzedniej dekadzie, efektywne działania w zakresie ograniczania zdrowotnych następstw palenia tytoniu, w szczególności leczenie zespołu uzależnienia od tytoniu, pozostaje najskuteczniejszym sposobem na zatrzymanie niekorzystnych tendencji związanych z umieralnością na nowotwory płuca. W populacjach Europy, gdzie nowotwory złośliwe płuca są prawie wyłącznie związane z aktywnym paleniem tytoniu, wysiłki środowisk działających w obszarze zdrowia publicznego powinny być skupione na wspieraniu działań dążących do zmniejszenia odsetka palących.W przypadku narastającej wśród kobiet epidemii wydaje się niezwykle ważne uwzględnienie specyfiki tej grupy populacji w planowaniu działań prewencyjnych. Kobiety z innych przyczyn niż mężczyźni rozpoczynają palenie tytoniu i pełni ono innego rodzaju rolę w ich życiu; często także zupełnie inne przyczyny prowadzą u kobiet i mężczyzn do podjęcia decyzji o zaprzestaniu palenia. Dokładna analiza zwyczaju palenia wśród kobiet, z uwzględnieniem tej różnorodności na każdym etapie, wydaje się być kluczem do osiągnięcia sukcesu na polu prewencji pierwotnej nowotworów tytoniozależnych. Wiedzę w tym zakresie doskonale wykorzystują strategie marketingowe przemysłu tytoniowego, dostosowując swoje produkty do żeńskiego konsumenta, produkując coraz bardziej atrakcyjne opakowania, stosując dodatki smakowe czy budując przekonanie, że pewne produkty są mniej niebezpieczne od innych bądź pozwalają osiągnąć dodatkowe korzyści, na przykład utratę wagi. Problem ten został dostrzeżony przez Komisję Europejskąjuż wiele lat temu. Przygotowywała ona dyrektywę próbującą wprowadzić ograniczenia produkcji papierosów typu „mentol" czy „slim" [16].

Inną, niezmiernie istotną kwestią jest wspieranie obecnie palących kobiet w zaprzestaniu palenia, obalanie mitów związanych z korzyściami, w szczególności niezwykle silnie funkcjonującego wświadomości kobiet mitu dotyczącego utrzymania prawidłowej masy ciała dzięki paleniu tytoniu. Edukowanie kobiet w tym zakresie, a także wskazywanie efektywnych sposobów rozstania się z papierosem, w tym zalecanie skutecznej farmakoterapii oraz zapewnienie wsparcia psychologicznego, powinno pozostawać priorytetem w zakresie działań prewencji pierwotnej nowotworów i promocji zdrowia.

Ograniczeniem analizy zaprezentowanej w tym artykule jest przedłużenie linii trendów do 2020 roku, mające na celu wskazanie dalszego przebiegu umieralności przy założeniu kontynuacji trendu obserwowanego w ostatnich latach. Należy podkreślić, że nie jest to prognoza uwzględniająca zmiany populacyjne, wpływ badań przesiewowych czy postępów w leczeniu, a jedynie zabieg służący łatwiejszemu zobrazowaniu sytuacji.

\section{Wnioski}

Rak piersi, będący od lat najczęstszą przyczyną zgonów w populacji kobiet w Europie, przestaje byćjuż nowotworem dominującym, a nowotwory złośliwe płuca stają się pierwszą przyczyną zgonów nowotworowych wśród kobiet. W Polsce już od 2003 roku jest to pierwsza przyczyna umieralności nowotworowej kobiet w wieku 45-74 lat. Leczenie zespołu uzależnienia od tytoniu wydaje się być najskuteczniejszym sposobem na zmianę tych niekorzystnych tendencji. Szerokie działania edukacyjne, skierowane szczególnie do kobiet, oraz wskazywanie efektywnych sposobów zerwania 
z paleniem papierosów powinno pozostawać priorytetem w zakresie działań prewencji pierwotnej nowotworów i promocji zdrowia w Polsce i w Europie.

\section{Konflikt interesów: nie zgłoszono}

Lista stosowanych skrótów:

UE — Unia Europejska

WHO - Światowa Organizacja Zdrowia

ICD — Międzynarodowa Klasyfikacja Chorób

\section{Mgr Urszula Sulkowska}

Zakład Epidemiologii

Centrum Onkologii — Instytut im. Marii Skłodowskiej Curie

ul. Wawelska 15, 02-034 Warszawa

e-mail: sulkowskau@coi.waw.pl

Otrzymano: 15 maja $2015 \mathrm{r}$.

Przyjęto do druku: 23 czerwca 2015 r.

\section{Piśmiennictwo}

1. WHO Mortality Database. Health statistics and information systems. Dostępny na: http://www.who.int/healthinfo/mortality_data/en/.

2. Jemal A, Bray F, Center MM i wsp. Global cancer statistics. CA Cancer J Clin 2011; 61:69-90.

3. Bosetti C, Bertuccio P, Levi F i wsp. The decline in breast cancer mortality in Europe: An update (to 2009). Breast 2012; 21: 77-82.
4. Stoeldraijer L, Bonneux L, van Duin C i wsp. The future of smoking-attributable mortality: the case of England \& Wales, Denmark and the Netherlands. Addiction 2014; doi: 10.1111/add.12775.

5. Juel K. Increased mortality among Danish women: population based register study. BMJ 2000; 321: 349-350.

6. Globalny sondaż dotyczący używania tytoniu przez osoby dorosłe (GATS). Polska 2009-2010. Warszawa; Ministerstwo Zdrowia; 2010.

7. Gallus S, Lugo A, La Vecchia C i wsp. Pricing Policies And Control of Tobacco in Europe (PPACTE) project: cross-national comparison of smoking prevalence in 18 European countries. Eur J Cancer Prev 2014; 23: $177-185$

8. Tombor I, Paksi B, Urban R i wsp. [Epidemiology of smoking in Hungary-a representative national study]. Orv Hetil 2010; 151: 330-337.

9. ZatońskiW, Przewoźniak K, Sulkowska U i wsp. Tobacco smoking in countries of the European Union. Ann Agric Environ Med 2012; 19: 181-192.

10. Helasoja VV, Lahelma E, Prattala RS i wsp. Determinants of daily smoking in Estonia, Latvia, Lithuania, and Finland in 1994-2002. Scand J Public Health 2006; 34: 353-362.

11. Graham H. Smoking prevalence among women in the European community 1950-1990. Soc Sci Med 1996; 43: 243-254.

12. Brown J, West R. Smoking prevalence in England is below $20 \%$ for the first time in 80 years. BMJ 2014; 348: g1378.

13. Lew DT, Currie L, Clancy L. Tobacco control policy in the UK: blueprint for the rest of Europe? Eur J Public Health 2013; 23: 201-206.

14. Kabir Z, Bennett K, Shelley E i wsp. Comparing primary prevention with secondary prevention to explain decreasing coronary heart disease death rates in Ireland, 1985-2000. BMC Public Health 2007; 7:117.

15. Currie LM, Blackman K, Clancy L i wsp. The effect of tobacco contro policies on smoking prevalence and smoking-attributable deaths in Ireland using the IrelandSS simulation model. Tob Control 2013; 22: e25-e32.

16. Zatoński W, Zatoński M, Przewoźniak K. Health improvement in Poland is contingent on continued extensive tobacco control measures. Ann Agric Environ Med 2013; 20: 405-411. 